\title{
Deoxyribonucleic Acid Measurement
}

National Cancer Institute

\section{Source}

National Cancer Institute. Deoxyribonucleic Acid Measurement. NCI Thesaurus. Code C135409.

The determination of the amount of deoxyribonucleic acid (DNA) in a biological sample. 